Meta

Journal des tradlucteurs

Translators' Journal

\title{
Art and Juri-Linguistics. Strange Bedfellows or Inseparable Companions?
}

\section{Wallace Schwab}

Volume 47, numéro 2, juin 2002

Traduction et terminologie juridiques

URI : https://id.erudit.org/iderudit/008004ar

DOI : https://doi.org/10.7202/008004ar

Aller au sommaire du numéro

Éditeur(s)

Les Presses de l'Université de Montréal

ISSN

0026-0452 (imprimé)

1492-1421 (numérique)

Découvrir la revue

Citer cet article

Schwab, W. (2002). Art and Juri-Linguistics. Strange Bedfellows or Inseparable Companions? Meta, 47(2), 154-154. https://doi.org/10.7202/008004ar d'utilisation que vous pouvez consulter en ligne.

https://apropos.erudit.org/fr/usagers/politique-dutilisation/ 


\section{Art and Juri-Linguistics. Strange Bedfellows or Inseparable Companions?}

The Language of the Law, if such a thing exists as some might maintain, is often a topic central to wordsmiths who must struggle with the multifarious manifestations and demands of expressing legal thinking, sometimes in only one language and at others in fifteen or dozens of languages. A truism of yesterday, today and tomorrow, the current contribution to this ongoing dialogue-as you will read-defines, explains, illustrates, teaches, categorizes, and dissects the workings of language when harnessed to express formal relations between human beings across language barriers. A fathomless subject!

The bedrock for expressing legal relationships resides in the skilful, even artistic use of drafting and verbal techniques that fulfill one fundamental need: the adequate transmission of a message. Yet the acquisition and exercising of such techniquesoften hermetic and indispensable-take root in the encyclopaedic understanding of peoples, their inherited values and social organizations. In other words, we are dealing with techniques deeply rooted in the legal traditions of distinctive cultures!

Cultures I say? Traditions with their uses and customs in unitary systems of law are pervasive throughout the civilizations that use them to govern formal relationships. In these systems, positivists may construe in the comfort of isolation while their pluralistic colleagues question the value of constructions made in vitro. As the product of such thinking seeps across language divides into foreign systems via interpreters, terminologists and translators, it becomes food for thought, the coarse bread that juri-linguists must break evenly to satisfy hungry and discriminating masses.

In these circumstances, artistic expertise with sensitivity and imagination in the mastery of down-to-earth techniques - where theory transubstantiates into practicetakes command over asymmetric systems of societal symbols, norms and linguistic expressions in order to produce pragmatic or functional communication. In doing so, if all parties to a multilingual legal document or utterance find themselves complying "jointly and severally" with a same set of standards, then there is an argument for promoting an artistic approach to juri-linguistics founded upon knowledge of and respect for cultural differences and their techniques sui generis.

Incidentally, the answer to my opening question in my view is: They are both at once.

Now, read on and enjoy!

Wallace Schwab

Certified Translator and Terminologist,

Ordre des traducteurs, terminologues et interprètes agréés du Québec, Canada 